ISSN: 2302-8556

E-Jurnal Akuntansi Universitas Udayana

Vol.22.3. Maret (2018): 2065-2087

DOI: https://doi.org/10.24843/EJA.2018.v22.i03.p16

\title{
Pengaruh PAD, DAU Dan DAK Pada Alokasi Belanja Modal dengan Pendapatan Per Kapita Sebagai Pemoderasi
}

\author{
Desak Made Mya Yudia Sari ${ }^{1}$ \\ Dewa Gede Wirama ${ }^{2}$
}

${ }^{1}$ Fakultas Ekonomi dan Bisnis Universitas Udayana (Unud), Bali, Indonesia email: myayudiasari@yahoo.com/Telp: +62 87861484979

${ }^{2}$ Fakultas Ekonomi dan Bisnis Universitas Udayana (Unud), Bali, Indonesia

\begin{abstract}
ABSTRAK
Tujuan pengujianadalah untuk mengetahui pengaruh pendapatan, asli daerah, dana alokasi umum, dan dana alokasi khusus pada alokasi belanja modal serta untuk mengetahui apakah pad, dau dan dak pada alokasi belanja modal dimoderasi oleh pendapatan per kapita. Sampel penelitian ini adalah pemerintah Kota/Kabupatense-Bali periode tahun 2012-2016, yang menghasilkan 45 amatan. Teknik analisis data yang digunakan adalah teknik analisis regresi linier berganda dan moderated regression analysis.Berdasarkan hasil analisis diketahui bahwa pad dan dau berpengaruh positif pada alokasi belanja modal sedangkan dau tidak berpengaruh pada alokasi belanja modal. Pendapatan per kapita tidak memoderasi pad, dau, dan dak pada alokasi belanja modal.

Kata Kunci: Pendapatan asli daerah, dana alokasi umum, dana alokasi khusus, pendapatan per kapita, dan alokasi belanja modal
\end{abstract}

\begin{abstract}
The purpose of study is to determine the effect of original local government, general allocation funds, special allocation fund, in the allocation of capital expenditures and to determine whether the influence of pad, dau, and dak the allocation of capital expenditure is moderated by percapita income. The sample of this research is government of City/Regency in Bali during the period of 2012-2016, resulting in 45 observations. Data analysis techniques used are multiple linier regression analysisand analysis moderated regression. Based in the analysis it is known that pad and dau havepositive effects on the allocation of capital expenditure while dak does not affect the allocation of capital expenditure. Percapita income does not moderate the effects of pad, dau and dak on capital expenditure allocations.

Keyword: Original local government, general allocation funds, special allocation fund, per capita income, andcapital expenditure
\end{abstract}

\section{PENDAHULUAN}

Belanja modal digunakan sebagai memperoleh aset tetap pemerintah daerah (pemda) seperti peralatan, infrastruktur, dan harta benda tetap lainnya. Pemerintah daerah memiliki aset tetap dengan penyebab ada belanja modal yang berarti salah satu persyaratan untuk pelayanan public.Peraturan Menteri Dalam Negeri (Permendagri)No 59 Th 2007, belanja modal digunakan untuk pengeluaran yang 
dilaksanakan dalam rangka pengadaan aset tetap berwujud yang mempunyai nilai kegunaan> 12 (dua belas) bulan untuk digunakan dalam program pemerintahaan. Pemerintah daerah memperoleh penambahan aset dengan membeli. Belanja modal bertujuan untuk menyediakan sarana dan prasarana fasilitas publik yang dapat menjadi penunjang terlaksananya berbagai aktivitas ekonomi masyarakat. Belanja modal berpengaruh penting terhadap pertumbuhan ekonomi karena akan menggerakkan roda perekonomian daerah. Pengalokasian belanja modal yang lebih tinggi seharusnya bisa dilakukan oleh pemerintah daerah dibandingkan dengan belanja rutin yang kurang bermanfaat (Felix, 2012).

Pengalokasiananggaran belanja modal dikatakanberhasilan apabila pemerintah daerah mampu memberikan pelayanan kepada publik, sebaiknya digunakan dalam perihal yang efisien dan efektif, misalnya untuk pembangunan (Darwanto dan Yustikasari, 2007). Faktor-faktor yang mempengaruhi belanja modal sudah cukup banyak diteliti. Darwanto dan Yustikasari (2007) menyimpulkan pendapatan asli daerah (PAD), pertumbuhan ekonomi, dan dana alokasi umum (DAU) berpengaruh pada alokasi anggaran belanja modal. Tuasikal (2008) menyimpulkan DAU, dana alokasi khusus (DAK), dan PAD berpengaruh positif pada alokasi belanja modal, sementara produk domestik regional bruto (PDRB) tidak berpengaruh.

Sumarmi (2009) menyimpulkan PAD dan DAK berpengaruh positif pada alokasi belanja modal, sementara DAU berpengaruh negatif. Syafitri (2009) menyimpulkan PAD berpengaruh positif pada pengalokasian anggaran belanja modal, sementara PDRB dan DAU tidak berpengaruh. Harahap (2010) 
menyimpulkanDana Bagi Hasil (DBH) pajak berpengaruh signifikan positif pada belanja modal, sementara dana bagi hasil sumber daya alam tidak berpengaruh. Putro (2011) menyimpulkan DAU berpengaruh positif pada anggaran belanja modal, sementara pertumbuhan ekonomi dan PAD tidak berpengaruh.

Ardhani (2011) menyimpulkan PAD dan DAU berpengaruh positif pada belanja modal, sementara pertumbuhan ekonomi dan DAK tidak berpengaruh. Sianipar (2011) menyimpulkan PAD, DAU, dan DAK berpengaruh positif pada belanja modal, sementara dana bagi hasil pajak dan dana bagi hasil sumber daya alam tidak berpengaruh. Yovita (2011) menyimpulkan pertumbuhan ekonomi berpengaruh positif pada pengalokasian anggaran belanja modal, DAU berpengaruh negatif, sementara PAD tidak berpengaruh. Kusnandar dan Dodik (2012) menyimpulkan PAD, Sisa Lebih Pembiayaan Anggaran (SiLPA) dan luas wilayah berpengaruh positif pada belanja modal, sementara DAU tidak berpengaruh.

Oktora dan Pontoh (2013) menyimpulkanDAK dan DAU berpengaruh positif pada belanja modal, sementara PAD tidak berpengaruh. Santosa dan Rofiq (2013) menyimpulkanDAU dan PAD berpengaruh positif pada belanja modal, sementara DAK tidak berpengaruh. Siregar (2013) menyimpulkanDBH sumber daya alam berpengaruh positif pada belanja modal, sementara PAD, DAU, dan DBH pajak tidak berpengaruh. Wandira (2013) menyimpulkan DAK dan DBH berpengaruh positif pada pengalokasian belanja modal, DAU berpengaruh negatif, sementara PAD tidak berpengaruh. Maryadi (2014) menyimpulkan DAU, DBH, 
SiLPA dan luas wilayah berpengaruh positif pada belanja modal, sementara PAD berpengaruh negatif.

Sebagai rangkuman uraian sebelumnya, faktor-faktor yang mempengaruhi alokasi belanja modal adalah pertumbuhan ekonomi, PAD, DAU, DAK, DBH (termasuk pajak dan sumber daya alam), SiLPA, dan luas wilayah. Penelitian ini menguji kembali pengaruh PAD, DAU, dan DAK sebagai variabel independen karena hanya ketiga variabel tersebut yang dapat dikontrol langsung oleh pemerintah.

Beragamnya hasil penelitian sebelumnya kemungkinan disebabkan oleh adanya variabel pemoderasi. Pengaruh variabel pemoderasi tersebut dapat bersifat positif maupun negatif (memperkuat atau memperlemah). Penelitian ini menggunakan pendapatan per kapita sebagai variabel pemoderasi. Pendapatan perkapita yaitubanyaknya pendapatan pemerataan masyarakat/penduduk di dalam wilayah tersebut dan digunakan daam mengukurkemakmuran sertapeningkatan pembangunan wilayah. Pendapatan per kapita diperoleh dengan membagi pdb nasional wilayah dengan banyaknyamasyarakat/penduduk pada wilayah itu.

Pendapatan per kapita diduga mampu untuk dapat memperkuat PAD pada alokasi belanja modal. Semakin besar pendapatan penduduk maka akan semakin tinggi kemampuan dari penduduk untuk membayar pajak atau retribusi yang telah diberlakukan. Hal tersebut dapat menambah sumber pendapatan daerah dan tentu saja akan membuat pendapatan PAD semakin meningkat yang selanjutnya dipergunakan untuk memberikan pelayanan publik. Apabila peningkatan PAD dapat mendorong pertumbuhan ekonomi daerah, maka terdapat kemungkinan 
pendapatan per kapita memperkuat pengaruh DAU dan DAK pada belanja modal, karena pada umumnya nilai DAU dan DAK lebih besar dibandingkan kontribusi PAD.

Berkaitan dengan dana perimbangan pemerintah daerah dan pusat, DAU adalah salah satu sumber untuk menambah belanja modal. Selanjutnya, DAK dimaksud dalam rangka pembiayaan sarana dan prasarana layanan masyarakat yang tidaktercapai dalam standar yang telah ditetapkan.Hayek (1945) mengemukakan mengenai teori tradisional yang menekankan keuntungan alokatif dari desentralisasi sementara Musgrave (1959) dan Oates (1972), menekankan bagaimana desentralisasi fiskal mempengaruhi perilaku pemerintah daerah.Secara teori, kekuasaan dari pemerintah pusat ke pemerintah daerah yang dapat meningkatkan atau mengurangi pertumbuhan ekonomidan devolusi tanggung jawab fiskal adalah desentralisasi fiskal (Bodman et al, 2009).

DAU dan DAK pada belanja modal dapat diperkuat oleh alokasi belanja modal. Semakin tingginya pertumbuhan ekonomi suatu daerah semestinya dapat meningkatkan DAU dan DAK pada alokasi belanja modal. Pertumbuhan ekonomi dari suatu daerah yang tinggi akan berdampak pada peningkatan pendapatan per kapita dari penduduknya, sehingga konsumsi dan produktivitas penduduk semakin tinggi. Selain daripada itu, semakin tinggi dana APBN dianggarkanbertujuan pemerataan keuangan antar daerah yang digunakanpembiayaan kebutuhan pengeluarannya dalamrangka desentralisasi yang tinggi selanjutnya akan digunakan oleh pemerintah daerah untuk memberikan pelayanan publik yang memadai sehingga hal ini akan meningkatkan belanja modal. 
Tujuan penelitian adalah untuk mendapatkan bukti empiris pengaruh PAD, DAU dan DAKpada alokasi belanja modal dan untuk mendapatkan bukti empiris apakah pendapatan per kapita memoderasi PAD, DAU dan DAK pada alokasi belanja modal.Kegunaan teoritis dari penelitian ini, diharapkan dapat memberikan pengetahuan yang lebih luas mengenai pengaruh PAD, DAU dan DAK pada alokasi belanja modal dengan pendapatan per kapita sebagai variabel pemoderasi serta dapat dijadikan perbandingan, pengembangan, memberikan kontribusi, dan penyempurnaan dari penelitian sebelumnya. Kegunaan praktis dari penelitian ini diharapkan memberikan kontribusi bagi pemerintah daerah maupun pemerintah pusat mengenai PAD, DAU dan DAK pada alokasi belanja modal dengan pendapatan per kapita sebagai variabel pemoderasi.

Teori kontinjensi membahas berbagai aspek kepemimpinan yang diterapkan pada keadaan tertentu saja tetapi tidak untuk keadaan yang lain. Teori kontinjensi juga bisa preskriptif atau deskriptif. Teori preskriptif menganalisis perilaku yang paling efisien dalam setiap keadaan, sementara teori deskriptif menganalisis tentang kenapa pemimpin berperilaku berbeda antara satu keadaan dengan keadaan lainnya (Yukl, 2010). Teori kontinjensi merupakan teori perilaku yang mengklaim bahwa tidak ada satu cara terbaik untuk merancang struktur organisasi. Cara terbaik untuk mengatur contohnya sebuah perusahaan, adalah bergantung pada situasi internal dan eksternal perusahaan. Keadaan masih diliputi dengan ketidakpastian tentang terdapat laba atau rugi oleh suatu perusahaan, yang terselesaikan dengan terjadi atau tidak terjadi banyak tidak hanya satu atauapun dua/lebih peristiwa dimasa berikutnya. 
Penelitian yang menerapkan pendekatan kontinjensi sudah cukup banyak diteliti, tidak hanya pada akuntansi manajeman. Pendekatan kontinjensi juga diterapkan dalam akuntansi sektor publik. Sistem akuntansi sektor publik merupakan suatu pendekatan kontinjesi dari faktor kondisional yang digunakan dalam penelitian sebagai variabel yang memoderasi suatu hubungan. Faktor kontinjensi yang digunakan adalah pendapatan per kapita.

Undang-Undang (UU) No. 33 Thn 2004 menjelaskan bahwa Pendapatan Asli Daerah yang selanjutnya disebut PAD adalah pendapatan yang diperoleh daerah yang dipungut berdasarkan peraturan perundang-undangan. PAD dapat dijadikan indikator dalam menilai tingkat kemandirian suatu daerah dalam mengelola keuangan daerah, semakin tinggi rasio PAD dibandingkan dengan jumlah pendapatan makin tinggi tingkat kemandirian suatu daerah. PAD diharapakan untuk membantu keuangan daerah. PAD bersumber dari 1) pajak daerah yang terdiri dari pajak provinsi dan pajak kabupaten/kota, 2) retribusi daerah, 3) hasil pengelolaan kekaayaan daerah yang dipisahkan, dan 4) lain-lain PAD yang sah.

Setiap kabupaten atau kota memiliki kemampuan yang berbeda-beda dalam hal mendanai kegiatan daerahnya, yang menyebabkan adanya ketimpangan fiskal. Untuk mengatasi ketimpangan fiskal ini pemerintah mengalokasian dana yang bersumber dari APBN dalam pendanaan pelaksanaan desentralisasi.Dana yang berasal dari pendapatan APBN yang dialokasikan dengan tujuan pemerataan dalam rangka pelaksanaan desentralisasi disebut dengan DAU sementara, dana yangberasal dari APBN yang dialokasikan kepada 
Desak Made Mya Yudia Sari dan Dewa Gede Wirama. Pengaruh...

daerah tertentu dengan tujuan program nasional yang pencapainnya tidak sesuai dengan standar tertentu.

Dana yang ditransfer dari pusat untuk pemerintah daerah diharapkan pemerintah mampu mengalokasikan DAU yang diperolehnya untuk membiayai alokasi belanja modal di daerahnya.DAUmempunya sifatyang pemakaiannyadikembalikan kepada daerah tersebut dengan kebutuhan dan prioritas daerah untuk peningkatan pelayanan kepada masyarakat dalam rangka otonomi daerah atau disebut Block Grant (Tamtomo, 2010).Manfaat dari DAKditujukan pada kegiatan memperbaiki sarana dan prasarana fisik dengan umur ekonomis yang panjang, termasuk pengadaan sarana fisik penunjang, pengadaan, peningkatan, serta investasi pembangunan. Dengan adanya pengalokasian anggaran belanja modal, DAK cenderungmeningkatkan aset tetap yang dimiliki pemerintah guna meningkatkan pelayanan publik.

Jika dilihat permasalahan, telah dikemukakan, kajian teoritis, dan tinjauan penelitian terdahulu dapat digambarkan kerangka konseptual dalam penelitian ini disajikan pada Gambar 1 seperti berikut.

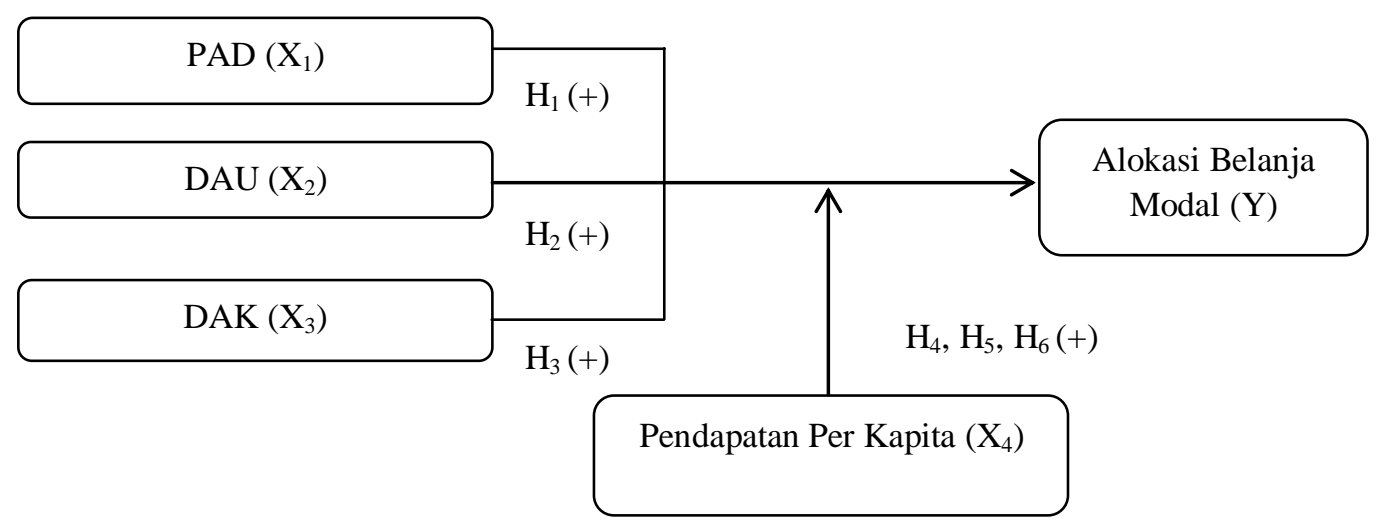

Gambar 1. Kerangka Konseptual 
Penelitian Darwanto dan Yustikasari (2007), Tuasikal (2008), dan Kussnandar dan Dodik (2012) menyatakan bahwa PAD berpengaruh positif pada alokasi belanja modal. Penemuan ini artinya, PAD merupakan faktor penentu dalam menentukan belanja modal. Penyusunan APBD, alokasi belanja modal disesuaikan dengan kebutuhanserta mempertimbangkan PAD yang diterima. Sehingga pemerintah daerah ingin menambah pos belanja modal dengan tujuan pelayanan publik dan kesjahteraan masyarakat, maka pemerintah daerah harus menggali PAD sebanyak - banyaknya.Berdasarkan hal tersebut, maka hipotesis yang dirumuskan adalah.

$\mathrm{H}_{1}$ : Pendapatan asli daerah berpengaruh positif pada alokasi belanja modal.

Sumarni (2008) dan Putro (2011) menyatakan DAU berpengaruh positif pada belanja modal. Sehingga pengaruh ini sangat kuat terhadap perilaku alokasi belanja modal yang dipengaruhi oleh penerimaan DAU.Pemaparandiatas menyimpulkan, semakin meningkat DAU maka alokasi belanja modal juga tinggi. Penyebabnya karena daerah mempunyai DAU yang banyak maka pengalokasian belanja modal akan meningkat. Berdasarkan hal tersebut, maka hipotesis yang dirumuskan berikut ini.

$\mathrm{H}_{2}$ : Dana alokasi umum berpengaruh positif pada alokasi belanja modal.

Latifah (2010) membuktikan bahwa DAK digunakan untuk menutup kesenjangan pelayanan publik antar daerah dengan memberi prioritas nasional. Sianipar (2011), Oktora dan Pontoh (2013) menyimpulkan DAK berpengaruh positif pada belanja modal. Pemaparan teori diatas dapat disimpulkan DAK dibagikan pada wilayah tertentu yang bertujuan membantu memberikan dana pada 
program khusus dengan skala nasional. Berdasarkan hal tersebut, maka hipotesis yang dirumuskan berikut.

$\mathrm{H}_{3}$ : Dana alokasi khusus berpengaruh positif pada alokasi belanja modal.

Peningkatan PAD harus berdampak pada perekonomian daerah (Saragih, 2003). Oleh karena itu, daerah tidak akan berhasil bila daerah tidak mengalami pertumbuhan ekonomi yang berarti meskipun terjadi peningkatan penerimaan PAD. Bila yang terjadi sebaliknya, maka bisa diindikasikan adanya eksploitasi PAD terhadap masyarakat secara berlebihan tanpa memperhatikan peningkatan produktifitas masyarakat itu sendiri. Sidik (2002) menegaskan bahwa keberhasilan peningkatan PAD hendaknya tidak hanya diukur dari jumlah yang diterima, tetapi juga diukur dengan perannya untuk mengatur perekonomian masyarakat agar dapat lebih berkembang, yang pada gilirannya dapat meningkatkan kesejahteraan masyarakat di daerah. Berdasarkan hal tersebut, maka hipotesis yang dirumuskan adalah sebagai berikut.

$\mathrm{H}_{4}$ : Pendapatan per kapita memperkuat pengaruh pendapatan asli daerah pada alokasi belanja modal.

DAU merupakan pendapatan daerah selain PAD, DAU merupakan dana transfer berasal dari APBN yang diberikan oleh pemerintah pusat. Tujuan diberikannya DAU yaitu agar meratanya keuangan daerah untuk membiayai program khusus yang dikeluarkan dalam rangka pelaksanaan desentralisasi (Wertianti, 2013). Adanya bantuan sumber pendanaan dari pemerintah pusat diharapkan pemerintah dapat mengalokasikan dana tersebut dengan bijak untuk membiayai belanja daerah, khususnya sektor publik. Peningkatan fasilitas publik dan infrastruktur publik kembali lagi akan menyejahterakan masyarakat, sehingga 
pada akhirnya akan meningkatkan pertumbuhan ekonomi (pendapatan per kapita) di daerah (Candra, 2014). Berdasarkan hal tersebut, maka hipotesis yang dirumuskan adalah sebagai berikut.

$\mathrm{H}_{5}$ : Pendapatan per kapita memperkuat pengaruh dana alokasi umum pada alokasi belanja modal.

DAK merupakan bagian pos dana perimbangan selain DAU. DAK merupakan pendanaan pendapatan APBN yang dialokasikan kepada daerah tertentu yang bertujuan sebagai pendanaan program khusus dengan skala nasional.Manfaat pendanaan alokasi khusus ini bertujuan padaprogram nasioanal yang mempunyai nilai ekonomis yang tinggi dan umur yang panjang (Ardhani, 2011). Diharpkan dengan adanya DAK dapat berpengaruh pada alokasi belanja modal disertai dengan meningkatnya pendapatan per kapita, karena DAK mengarah menambah aset tetap yang dipunyai oleh pemerintah yang bertujuan meningkatkan pelayanan publik. Berdasarkan hal tersebut, maka hipotesis yang dirumuskan adalah sebagai berikut.

$\mathrm{H}_{6}$ : Pendapatan per kapita memperkuat pengaruh dana alokasi khusus pada alokasi belanja modal.

\section{METODE PENELITIAN}

Penelitian ini dilakukan di Badan Pusat Statistik (BPS) Provinsi Bali. Ruang lingkup penelitian ini adalah kabupaten/kota se- Bali. Jenis data dan sumber data yang digunakan dalam penelitian ini adalah data kuantitatif dan data sekunder. Variabel bebas pada penelitian ini adalah PAD, DAU dan DAK, variabel terikat yaitu alokasi belanja modal serta pendapatan per kapita sebagai variabel moderasi. Penelitian ini populasinya adalah pemerintah kabupaten/kota se-Bali periode 
tahun 2012-2016. Sampel penelitian terdiri dari 1 kota madya dan 8 kabupaten periode tahun 2012-2016 dengan metode sampling jenuh. Metode pengumpulan data menggunakan metode dokumentasi dengan teknik analisis data yang digunakan adalah analisis regresi linier berganda dan moderated regression analysis.

Hipotesis dalam penelitin ini terdaat 6 (enam) hipotesis, dimana $\mathrm{H}_{1}, \mathrm{H}_{2}$, dan $\mathrm{H}_{3}$ yang bersumber dari penelitian sebelumnya diuji menggunakan analisis regresi linier berganda. Sementara 3 (tiga) hipotesis lainnya yaitu $\mathrm{H}_{4}, \mathrm{H}_{5}$, dan $\mathrm{H}_{6}$ berdasarkan penerapan teori kontinjensi pada topik penelitian yang diuji menggunakan uji interkasi yaitu moderated regression analysis. Uji asumsi klasik adalah persyaratan statistik yang dipenuhi pada analisis regresi linier berganda untuk mengetahui apakah data terdistribusi secara normal, model regresi tidak mengandung multikolinearitas, dan tidak terdapat masalah heterokedastisitas.Model regresi linier berganda ditunjukkan dalam persamaan berikut.

$Y=\alpha+\beta_{1} X_{1}+\beta_{2} X_{2}+\beta_{3} X_{3}+e$

Persamaan moderated regression analysis sebagai berikut.

$Y=\alpha+\beta_{1} X_{1}+\beta_{2} X_{2}+\beta_{3} X_{3}+\beta_{4} X_{4}+\beta_{5} X_{1} \cdot X_{4}+\beta_{6} X_{2} \cdot X_{4}+\beta_{7} X_{3} \cdot X_{4}+e$

\section{HASIL DAN PEMBAHASAN}

Statistik deskriptif memberikan gambaran atau deskripsi suatu data yang dilihati dari jumlah data amatan, nilai minimum, nilai maksimum, nilai rata-rata, dan standar devisiasi. 
Tabel 1.

Statistik Deskriptif

(dalam jutaan rupiah)

\begin{tabular}{lrrrrr}
\hline & N & \multicolumn{1}{c}{ Minimum } & Maksimum & \multicolumn{1}{l}{ Mean } & Standar Deviasi \\
\hline PAD & 45 & $39.843,60$ & $3.563 .459,64$ & $517.893,72$ & 8,20 \\
DAU & 45 & $286.763,10$ & $982.698,08$ & $570.417,83$ & 1,55 \\
DAK & 45 & 540,93 & $293.888,35$ & $68.341,70$ & $64.683,22$ \\
Pendapatan & 45 & 4,47 & 49,45 & 21,60 & 11,83 \\
Per Kapita & & & & \\
BM & 44 & $62.762,96$ & $1.195 .116,12$ & $259.942,83$ & 2,49 \\
\hline \multicolumn{2}{l}{ Sumber: Data diolah, 2018 }
\end{tabular}

Variabel PAD memiliki nilai terendah sebesar 39.843,60, nilai tertinggi sebesar 3.563.459,64, nilai rata-rata sebesar 517.893,72, dan standar deviasi yaitu 8,20.Variabel DAU memiliki nilai terendah sebesar $286.763,10$, nilai tertinggi sebesar 982.698,08, nilai rata-rata sebesar 570.417,83, dan standar deviasi yaitu 1,55.VaiabelDAKmemilikinilai terendah sebesar 540,930, nilai tertinggi sebesar 293.888,35, nilai rata-rata sebesar 68.341,70, dan standar deviasi yaitu 64.683,22. Variabel pendapatan per kapita yang diukur dengan PDB tahun t dibagi dengan juah penduduk tahun t memiliki nilai terendah sebesar 4,47 , nilai tertinggi sebesar 49,45, nilai rata-rata sebesar 21,60, dan standar deviasi yaitu 11,83. Variabel belanja modal memiliki nilai terendah sebesar $62.762,96$, nilai tertinggi sebesar 1.195.116,12, nilai rata-rata sebesar 259.942,83, dan standar deviasi yaitu 2,49 .

Uji normalitas bertujuan untuk menguji apakah dalam model regresi, variabel pengganggu atau residual memiliki distribusi normal. Pada pengujian ini dilihat besaran Kolmogorov-Smirnov (K-S) dan Asymp. Sig. (2-tailed)> 0,05.Nilai Kolmogorov-Smirnov (K-S) pada model regresi linier berganda adalah 0,544 dan signifikan pada 0,928. Selanjutnya pada hasil pengujian moderasi yang menggunakan persamaan moderated regression analysis, nilai Kolmogorov- 
Desak Made Mya Yudia Sari dan Dewa Gede Wirama. Pengaruh...

Smirnov (K-S) adalah 0,421 dan signifikan pada 0,994. Nilai tersebut menyimpulkan secara statistik Kolmogorov-Smirnov (K-S) dan Asymp. Sig. (2tailed)>0,05artinya data terdistribusi secara normal.

Tujuan dari uji multikolinearitas adalah menguji apakah model regresi ditemukan adanya korelasi antar variabel bebas. Untuk mendeteksi ada atau tidaknya multikolinearitas di dalam model regresi adalah dengan melihat (1) nilai tolerance dan lawannya, (2) variance inflation factor (VIF). Kedua ukuran ini menunjukkan setiap variabel bebas manakah yang dijelaskan oleh variabel bebas lainnya. Berdasarkan hasil analisis pada pengujian regresi linier berganda, nilai tolerance untuk variabel PAD 0,784 dan nilai VIF 1,275. Variabel DAU memiliki nilai tolerance 0,535 dan nilai VIF 1,869, sementara untuk variabel DAK nilai tolerance 0,652 dan nilai VIF 1,533. Jadi dapat disimpulkan bahwa model regresi dalam penelitin ini tidak mengandung multikolonieritas.

Pengujian pada model moderated regression analysis, nilai tolerance untuk variabel PAD 0,096 dan nilai VIF 10,390. Variabel DAU memiliki nilai tolerance 0,088 dan nilai VIF 11,423. Variabel DAK memiliki nilai tolerance 0,040 dan nilai VIF 25,097. Variabel pendapatan per kapita memiliki nilai tolerance 0,026 dan nilai VIF 38,709. Variabel PAD yang dimoderasi dengan pendapatan per kapita memiliki nilai tolerance 0,053 dan nilai VIF 18,946. Variabel DAU yang dimoderasi dengan pendapatan per kapita memiliki nilai tolerance 0,021 dan nilai VIF 46,772, sementara variabel DAK yang dimoderasi dengan pendapatan per kapita memiliki nilai tolerance 0,034 dan nilai VIF 29,772. Hasil penelitian menunjukkan nilai tolerencekeseluruhan variabel <0,1sertapenilaian VIF 
keseluruhan variabel $>10$, sehingga pada penelitian ini mengandung gejala multikolinearitas.

Uji glejser mengusulkan untuk meregres nilai absolut residual terhadap variabel bebas dengan menggunakan persamaat regresi dan melihat tingkat signifikansinya $>0,05$. Hasil pengujian heteroskesdastisitas pada model regresi linier berganda, variabel PAD memiliki nilai siginifikansi 0,885, variabel DAU memiliki nilai signifikansi 0,989 , dan variabel DAK memiliki nilai signifikansi 0,569. Jadi pada model regresi dalam penelitian initidak terjadi masalah heteroskedastisitas, karena nilai signifikansi $>0,05$.

Selanjutnya, pada model moderated regresssion analysis, untuk variabel PAD memiliki nilai signifikansi 0,880, variabel DAU memiliki nilai signifikansi 0,214, variabel DAK memiliki nilai signifikansi 0,757, variabel pendapatan per kapita memiliki nilai signifikansi 0,282 , variabel PAD yang dimoderasi oleh pendapatan per kapita memiliki nilai signifikansi 0,761 , variabel DAU yang dimoderasi oleh pendapatan per kapita memiliki nilai signifikansi 0,404 , dan variabel DAK yang dimoderasi oleh pendapatan per kapita memiliki nilai signifikansi 0,808 . Ini berarti tidak terjadi masalah heteroskedastisitas pada model regresi dalam penelitian ini, karena nilai signifikansi $>0,05$.

Intinyauji kelayakan model menunjukkan apakah semua variabel independen atau bebas yang dimasukkan dalam model mempunyai pengaruh secara bersama-sama terhadap variabel dependen/terikat. Untuk menguji hipotesis ini digunakan statistik F dengan kriteria nilai signifikansi $<0,05$. 
Tabel 2.

Uji Kelayakan Model

(Model Regresi Linier Berganda)

\begin{tabular}{rlrr}
\hline \multicolumn{1}{c}{ Model } & F & Sig. & \\
\hline 1 & Regression & & 0,000 \\
& Residual \\
Total & & 384,601 & \\
\hline Sumber: Data diolah, 2018 & & & \\
\hline
\end{tabular}

Sumber: Data diolah, 2018

Tabel 3.

Uji Kelayakan Model

(Model Moderated Regression Analysis)

\begin{tabular}{rlrr}
\hline \multicolumn{1}{c}{ Model } & F & Sig. \\
\hline 1 & Regression & 169,928 & 0,000 \\
& $\begin{array}{l}\text { Residual } \\
\text { Total }\end{array}$ & & \\
\hline Sumber: & Data diolah, 2018 & & \\
\hline
\end{tabular}

Berdasarkanhasil uji pada Tabel 2 nilai $F$ sebesar 384,601 dengan signifikansi 0,000 dan Tabel 3 nilai $\mathrm{F}$ sebesar 169,928 dengan signifikansi 0,000, memiliki arti bahwa variabelbebas (PAD, DAU dan DAK), pendapatan per kapita dan pemoderasi mempunyai pengaruhpadavariabeldependennyayaitu alokasibelanja modal.

Pada intinya koefisien determinasi digunakan untuk mengukur seberapa jauh kemampuan model dalam menerangkan variasi variabel dependen. Nilai koefisien determinasi adalah antara nol dan satu. Pada penelitian ini menggunakan nilai Adjusted R Square pada saat mengevaluasi mana model yang terbaik, karena nilai Adjusted R Square dapat naik atau turun apabila satu variabel independen ditambahkan kedalam model.

Tabel 4.

Koefisien Determinasi

(Model Regresi Linier Berganda)

\begin{tabular}{cccc}
\hline & Model & R Square & \multicolumn{2}{c}{ Adjusted R Square } \\
\hline 1 & 0,966 & 0,964 \\
\hline
\end{tabular}

Sumber: Data diolah, 2018 
Adjusted $R$ Square sebesar 0,964 yang berarti 96,4\% transisialoaksibelanja modal dapatdijelaskanolehvariabel PAD, DAU, dan DAK. Sedangkansisanya 3,6\% diakibatkanolehvariabel lain diluar model, misalnya hasil pengelolaan kekayaan daerah yang dipisahkan, retribusi daerah, pajak daerah, dbh pajak dan bukan pajak, serta dana penyesuaian.

Tabel 5.

Koefisien Determinasi (Model Moderated Regression Analysis)

\begin{tabular}{|c|c|c|}
\hline Model & R Square & Adjusted R Square \\
\hline 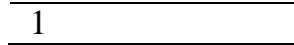 & 0,971 & 0,965 \\
\hline
\end{tabular}

NilaiAdjusted $R$ Squaresebesar 0,965 yang berarti $96,5 \%$ transisi aloaksibelanja modal dapatdijelaskanolehvariabel PAD, DAU, DAK, pendapatan per kapita dan pemoderasi. Sementara sisanya 3,5\% diakibatkanolehvariabel lain diluar model, misalnya hasil pengelolaan kekayaan daerah yang dipisahkan, retribusi daerah, pajak daerah, dbh pajak dan bukan pajak, serta dana penyesuaian.

Analisis regresi linier berganda adalah pengujian yang dilakukan untuk mengetahui ada tidaknya pengaruh PAD $\left(\mathrm{X}_{1}\right)$, DAU $\left(\mathrm{X}_{2}\right)$, dan DAK $\left(\mathrm{X}_{3}\right)$ pada alokasi belanja modal (Y). Hasil analisis dapat dijelaskan pada tabel berikut.

Tabel 6.

HasilAnalisis Regresi Linier Berganda

\begin{tabular}{lcrrrr}
\hline $\begin{array}{l}\text { Variabel } \\
\text { Terikat }\end{array}$ & VariabelBebas & $\begin{array}{c}\text { Koefisien } \\
\text { Regresi }\end{array}$ & $\begin{array}{c}\text { Standard } \\
\text { Error }\end{array}$ & t-hitung & Sig. \\
\hline Alokasi & PAD & 0,296 & 0,010 & 30,149 & 0,000 \\
Belanja & DAU & $-0,050$ & 0,063 & $-0,795$ & 0,431 \\
Modal & DAK & 0,669 & 0,137 & 4,886 & 0,000 \\
\hline Constant & $=88226,451$ & \multicolumn{3}{c}{ F-Hitung $=384,601$} \\
Adjusted $R$ Square $=0,964$ & \multicolumn{3}{c}{ Sig $=0,000$} \\
\hline
\end{tabular}

Sumber: Data diolah, 2018

Berdasarkan Tabel 6, dapat dilihat nilai signifikansi variabel PAD sebesar $0,000<0,05$ dan nilai koefisien regresi sebesar 0,296 . Hal ini menyimpulkanPAD 
berpengaruh positif pada alokasi belanja modal, sehingga $\mathrm{H}_{1}$ diterima.Signifikansi variabel DAU sebesar 0,431 >0,05 dan nilai koefisien regresi sebesar -0,050. Hasil inimenyimpulkanDAU tidak berpengaruh pada alokasi belanja modal, sehingga $\mathrm{H}_{2}$ ditolak. Nilai signifikansi variabel DAK sebesar $0,000<0,05$ dan nilai koefisien regresi sebesar 0,669 , jadi DAK berpengaruh positifpada alokasi belanja modal, sehingga $\mathrm{H}_{3}$ diterima.

Moderated regression analysis merupakan salah satu aplikasi khusus regresi linier berganda dimana dalam persamaan regresinya mengandung unsur interaksi (perkalian dua atau lebih variabel bebas). Hasil uji interaksi dapat dilihat pada Tabel 7.

Tabel 7.

Hasil Moderated Regression Analysis (MRA)

\begin{tabular}{|c|c|c|c|c|c|}
\hline \multirow[t]{2}{*}{ Variabel } & \multicolumn{2}{|c|}{$\begin{array}{l}\text { Unstandardized } \\
\text { Coefficients }\end{array}$} & \multirow{2}{*}{$\begin{array}{c}\text { Standardized } \\
\text { Coefficients } \\
\text { Beta }\end{array}$} & \multirow[t]{2}{*}{$\begin{array}{c}\mathrm{t}- \\
\text { hitung }\end{array}$} & \multirow[t]{2}{*}{ Sig. } \\
\hline & B & Std. Error & & & \\
\hline (Constant) & $-40055,905$ & 83217,618 & & $-0,481$ & 0,663 \\
\hline PAD & 0,331 & 0,28 & 1,102 & 11,963 & 0,000 \\
\hline DAU & 0,109 & 0,153 & 0,069 & 0,710 & 0,483 \\
\hline DAK & 0,878 & 0,547 & 0,230 & 1,606 & 0,117 \\
\hline PDRBperkapita & 6703,756 & 3720,261 & 0,320 & 1,802 & 0,080 \\
\hline PAD.PDRBperkapita & $-0,001$ & 0,001 & $-0,220$ & $-1,770$ & 0,085 \\
\hline DAU.PDRBperkapita & $-0,009$ & 0,006 & $-0,259$ & $-1,325$ & 0,193 \\
\hline DAK.PDRBperkapita & $-0,006$ & 0,018 & $-0,050$ & $-0,320$ & 0,751 \\
\hline Adjusted $\mathrm{R}^{2}$ & & & & & 0,965 \\
\hline F Hitung & & & & & 169,928 \\
\hline Sig. F & & & & & 0,000 \\
\hline
\end{tabular}

Berdasarkan persamaan regresi tersebut diketahui bahwa hasil nilai signifikansi uji hipotesis untuk variabel pendapatan per kapita memoderasi pengaruh PAD pada alokasi belanja modal senilai 0,085 dan nilai koefisien regresi sebesar -0,001, artinya pendapatan per kapita tidak memoderasi pengaruh PAD pada alokasi belanja modal, sehingga $\mathrm{H}_{4}$ ditolak. Nilai signifikansi uji hipotesis 
untuk variabel pendapatan per kapita memoderasi pengaruh DAU pada alokasi belanja modal senilai 0,193 dan nilai koefisien regresinya senilai-0,009, maka pengertiannya pendapatan per kapita tidak memoderasi pengaruh DAU pada alokasi belanja modal, sehingga $\mathrm{H}_{5}$ ditolak. Nilai signifikansi uji hipotesis untuk variabel pendapatan per kapita memoderasi DAK pada alokasi belanja modal senilai0,751 dan koefisien regresi sebesar-0,006, maka pengertiannya pendapatan per kapita tidakmemoderasi pengaruh DAK pada alokasi belanja modal, sehingga $\mathrm{H}_{6}$ ditolak.

\section{SIMPULAN}

Simpulan pengujian adalah pendapatan asli daerah dan dana alokasi khusus berpengaruh positif pada alokasi belanja modal di kota/kabupaten se-Bali tahun 2012-2016. Dana alokasi umum tidak berpengaruh pada alokasi belanja modal di kabupaten/kota se-Bali tahun 2012-2016. Pendapatan per kapita tidak memoderasi pendapatan asli daerah, dana alokasi umum dan dana alokasi khusus pada alokasi belanja modal di kabupaten/kota se-Bali tahun 2012-2016.

Pemerintah daerah diminta supaya mengembangkan potensi dan faktorfaktor ekonomi daerah untuk dapat menambah PAD, agar daerah tersebut dapat berdiri sendiri dan dapat memanfaatkan PAD, DAU dan DAK dengan sebijak mungkin untuk meningkatkan pelayanan publik. Hasil penelitian ini diharapkan dapat membantu dalam mengkaji secara dini kemampuan keuangan pemerintah kabupaten/kota di Provinsi Bali sebelum membuat kebijakan dalam rangka mencari sumber penerimaan daerah yang baru, serta sebagai masukan dan 
informasi dalam memberikan alternatif kebijakan yang berkaitan dengan pelaksanaan manajemen keuangan daerah.

Berdasarkan hasil penelitian ini yang menyatakan PAD berpengaruh positif pada alokasi belanja modal, dapat mengindikasikan bahwa besarnya pendapatan asli daerah menjadi salah satu faktor penentu dalam menentukan alokasi belanja modal. Setiap penyusunan APBD, alokasi belanja modal harus disesuaikan dengan kebutuhan daerah dengan mempertimbangkan pendapatan asli daerah yang diterima. Sehingga apabila pemerintah daerah ingin meningkatkan belanja modal untuk pelayanan publik dan kesejahteraan masyarakat, maka pemerintah daerah harus menggali pendapatan asli daerah yang sebanyaknya. Semakin banyaknya pendapatan asli daerah makadari itu pengeluaran pemerintah atas alokasi belanja modal menjadi meningkat.

Hasil yang didapat dari penelitian ini yang menyatakan bahwa DAK berpengaruh positf pada alokasi belanja modal, ini berarti dana alokasi khusus mempunyai hubungan yang sangat erat dengan alokasi belanja modal karena pendanaannya dari APBN pengalokasiannya pada kegiatan peningkatan, pengadaan, perbaikan sarana dan prasarana dengan umur ekonomis yang panjang, serta investasi pembangunan. Semakin tinggi dana alokasi khusus yang diperoleh dari pemerintah pusat maka alokasi belanja modal juga akan semakin meningkat.

\section{REFERENSI}

Ardhani, Pungky. 2011. Pengaruh Pertumbuhan Ekonomi, Pendapatan Asli Daerah, Dana Alokasi Umum, dan Dana Alokasi Khusus terhadap Pengalokasian Anggaran Belanja Modal. Skripsi Sarjana Jurusan Akuntansi pada Fakultas Ekonomi Universitas Diponegoro, Semarang. 
Ardhini. 2011. Pengaruh Rasio Keuangan Daerah Terhadap Belanja Modal Untuk Pelayanan Publik Dalam Prespektif Teori Keagenan (studi pada kabupaten dan kota di Jawa Tengah). Skripsi Sarjana Jurusan Akuntansi pada Fakultas Ekonomi Universitas Diponegoro, Semarang.

Bodman, P., Kelly Ana Heaton and Andrew Hodge. 2009. Fiscal Decentralisation and Economic Growth:A Bayesian Model Averaging Approach. Macroconomics Research Groupof School of Economics, The University of Queensland ST. Lucia 4072 Australia.

Candra Gunantara, Putu. 2013. Pengaruh Pendapatan Asli Daerah dan Dana Alokasi Umum Terhadap Pertumbuhan Ekonomi Dengan Belanja Modal Sebagai Variabel Pemodrasi di Provinsi Bali. Skripsi Sarjana Jurusan Akuntansi pada Fakultas Ekonomi dan Bisnis Universitas Udayana, Bali.

Darwanto dan Yustikasari, Yulia. 2007. Pengaruh Pertumbuhan Ekonomi, Pendapatan Asli Daerah, Dan Dana Alokasi Umum Terhadap Pengalokasian Anggaran Belanja Modal. Simposium Nasional Akuntansi X, Unhas Makassar 26-28 Juli 2007.

Felix, Olurankinse. 2012. Analysis of the effectiveness of capital expenditure budgeting in the local government system of Ondo State, Nigeria. Journal of Accounting and Taxation, 4(1), pp: 1-6.

Harahap, Alfan. 2010. Pengaruh Dana Bagi Hasil Pajak dan Dana Sumber Daya Alam terhadap Belanja Modal Pada Kabupaten/Kota di Sumatera Utara. Skripsi Sarjana Jurusan Akuntansi pada Fakultas Ekonomi dan Bisnis Universitas Sumatera Utara, Medan.

Hayek, Friedrich. 1945. The Use of Knowledge in Society. American Economic Review, 35: 519-530.

Kusnandar dan Dodik Siswantoro. 2012. Pengaruh Dana Alokasi Umum, Pendapatan Asli Daerah, Sisa Lebih Pembiayaan Anggaran dan Luas Wilayah Terhadap Belanja Modal.

Marryadi, 2014. Pengaruh PAD, DAU, DBH, SiLPA, dan Luas Wilayah Terhadap Belanja Modal Pada Kabupaten/Kota di Indonesia Tahun 2012. Skripsi Sarjana Jurusan Akuntansi pada Universitas Maritim Raja Ali Haji Tanjungpinang, Kepulauan Riau.

Musgrave, Richard.1959. Theory of Public Finance: A Study in Public Economy, New York: McGraw.

Oates, W.E. 1972. Fiscal Decentralization and Economic Development. National Tax Journal 46. 
Oktora, F.E. dan W. Pontoh. 2013. Analisis Hubungan Pendapatan Asli Daerah, DanaAlokasi Umum, dan Dana Alokasi Khusus atas Belanja Modal (Pada Pemerintah Daerah Kabupaten Tolitoli Provinsi Sulawesi Tengah). Jurnal Accountability. Vol. 2 (1).

Putro, Nugroho Suratmo \& Pamudji, Sugeng. 2011. Pengaruh Pertumbuhan Ekonomi, Pendapatan Asli Daerah Dan Dana Alokasi Umum Terhadap Pengalokasian Anggaran Belanja Modal (Studi Kasus Pada Kabupaten/Kota di Provinsi Jawa Tengah). Skripsi Sarjana Jurusan Akuntansi pada Fakultas Ekonomi Universitas Diponegoro, Semarang.

Santosa, A.B. dan M.A. Rofiq. 2013. Pengaruh Pendapatan Asli Daerah (PAD), Dana AlokasiUmum (DAU) dan Dana Alokasi Khusus (DAK) terhadap Belanja Modal pada Kabupaten/Kota (Studi Kasus di Provinsi Jawa Barat, Jawa Tengah dan Jawa Timur Periode Tahun 2007-2010). Jurnal Bisnis dan Ekonomi (JBE). Vol. 2 (2).

Saragih, Juli Panglima. 2003. Desentralisasi Fiskal \& Keuangan Daerah dalam Otonomi. Ghalia Indonesia.

Sianipar, Eva Septriani. 2011. Analisis Pengaruh Pendapatan Asli Daerah (PAD) dan Dana Perimbangan terhadap Pengalokasian Belanja Modal pada Kabupaten/Kota di Sumatera Utara. Skripsi Sarjana Jurusan Akuntansi pada Fakultas Ekonomi dan Bisnis Universitas Sumatera Utara, Medan.

Sidik, Machfud. 2002. Kebijakan Implementasi dan Pandangan Ke Depan Perimbangan Keuangan Pusat dan Daerah. Yogyakarta.

Siregar, Anggi Rezeki. 2013. Pengaruh Pendapatan Asli Daerah dan Dana Transfer yang terdiri dari Dana Alokasi Umum, Dana Bagi Hasil Pajak dan Sumber Daya Alam terhadap Belanja Modal pada Kabupaten/Kota di Aceh. Skirpsi Sarjana Jurusan Akuntans pada Fakultas Ekonomi dan Bisnis Universitas Sumatera Utara, Medan.

Sumarmi, S. 2009. Pengaruh Pendapatan Asli Daerah, Dana Alokasi Umum, Dana Alokasi Khusus terhadap Belanja Modal Daerah Kabupaten/Kota di Provinsi D.I.Yogyakarta. Skrpsi Sarjana Jurusan Akuntansi pada Fakultas Ekonomi Universitas PGRI, Yogyakarta.

Syafitri. 2009. Pengaruh Pertumbuhan Ekonomi, Pendapatan Asli Daerah,dan Dana Alokasi Umum terhadap pengalokasian anggaran belanja modal pada pemerintah kabupaten/kota di Provinsi Sumatra Utara. Skripsi Sarjana Jurusan Akuntansi pada Fakultas Ekonomi dan Bisnis Universitas Sumatera Utara, Medan. 
Tamtomo, Edi. 2010. Analisis Pertumbuhan Ekonomi Daerah di Era Desentralisasi Fiskal (Studi Kasus Kab/Kota di Provinsi Jawa Tenfgah). Jurnal Akuntansi pada Fakultas Ekonomi dan Bisnis Universitas Indonesia, Jakarta.

Tuasikal, Askam. 2008. Pengaruh DAU, DAK, PAD dan PDRB Terhadap Belanja Modal Pemerintah Daerah Kabupaten/Kota di Indonesia. Jurnal Telaah \& Riset Akuntansi, 1(2), hal. 142-155.

Wertianti, I G A Gede. 2013. Pengaruh Pertumbuhan Ekonomi Terhadap Belanja Modal dengan PAD dan DAU sebagai Variabel Moderasi di Kabupaten/Kota Provinsi Bali. Skripsi Sarjana Jurusan Akuntansi ada Fakultas Ekonomi dan Bisnis Universitas Udayana, Bali.

Yovita, Farah Marta. 2011. Pengaruh Pertumbuhan Ekonomi, Pendapatan Asli Daerah dan Dana Alokasi Umum terhadap Pengalokasian Anggaran Belanja Modal (Studi Empiris Pada Pemerintah Provinsi Se Indonesia Periode 2008 - 2010). Skripsi Sarjana Jurusan Akuntansi pada Fakultas Ekonomi Universitas Diponegoro, Semarang. 